\title{
Determinants of Students' Perceived Learning Outcome and Satisfaction in Online Learning during the Pandemic of COVID 19
}

\author{
Hasnan Baber \\ Endicott College of International Studies, Woosong University, Daejeon, South Korea. \\ Email: h.baber@endicott.ac.kr.Tel:+82-010-2750-3750
}

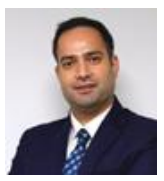

\begin{abstract}
The COVID19 pandemic has disrupted the normal functioning of various activities across the world, including learning and education. The shift towards online education during the pandemic of COVID19 has led many studies to focus on perceived learning outcomes and student satisfaction in this new learning environment. This study aims to examine the determinants resulting in students' perceived learning outcomes and their influence on student satisfaction. The data was collected from undergraduate students in both South Korea and India to gain a crosscountry study. The study found that the factors-interaction in the classroom, student motivation, course structure, instructor knowledge, and facilitation-are positively influencing students' perceived learning outcome and student satisfaction. There is no significant difference in the students' perceived learning outcome and student satisfaction in the two countries. The study will be helpful for the educationists and academics to identify the factors which will enhance student learning outcome and satisfaction level in online classes during the coronavirus pandemic.
\end{abstract}

Keywords: Perceived, Learning, Satisfaction, Student; Instructor, Online, E-Learning, COVID 19, Coronavirus, Pandemic.

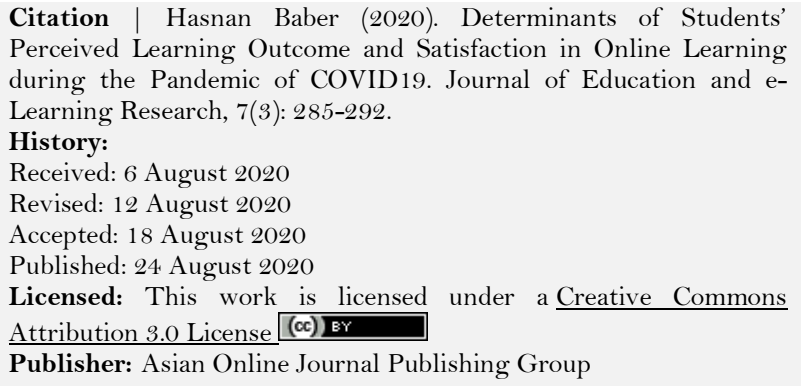

Citation | Hasnan Baber (2020). Determinants of Students' Perceived Learning Outcome and Satisfaction in Online Learning during the Pandemic of COVID19. Journal of Education and eLearning Research, 7(3): 285-292.

History:

Received: 6 August 2020

Revised: 12 August 2020

Accepted: 18 August 2020

Accepted: 18 August 2020

Licensed: This work is licensed under a Creative Commons

Attribution 3.0 License (cc) E

Publisher: Asian Online Journal Publishing Group

Contents

1. Introduction

Funding: This study will receive support from Woosong Academic Research Funding 2020

Competing Interests: The author declares that there are no conflicts of interests regarding the publication of this paper.

Transparency: The author confirms that the manuscript is an honest, accurate, and transparent account of the study was reported; that no vital features of the study have been omitted; and that any discrepancies from the study as planned have been explained.

Ethical: This study follows all ethical practices during writing.

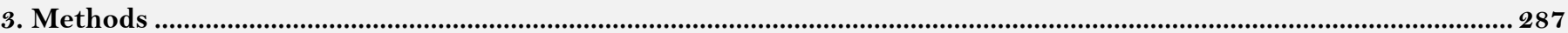

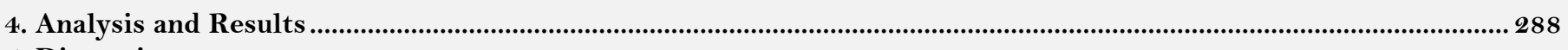

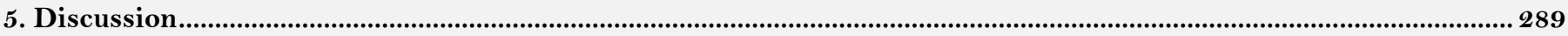

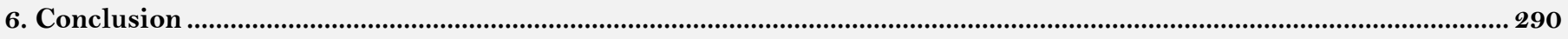

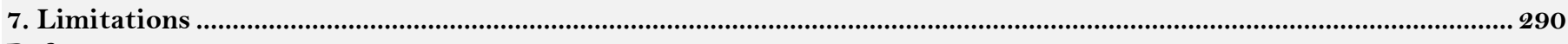

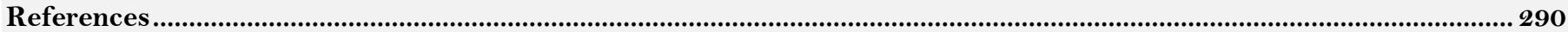




\section{Contribution of this paper to the literature}

The study contributes to existing literature by examining the determinants resulting in students' perceived learning outcomes and their influence on student satisfaction.

\section{Introduction}

Online learning refers to an electronic learning environment where, unlike traditional learning, there are no physical peer learners, and there is freedom of time and space. However, e-learning makes learning flexible and provides an alternative for those who cannot attend traditional classrooms for any reason. With the growth of technology and the Internet, e-learning has secured a good position in an academic world. At times, e-learning is included in the category of distance education (Bates, 2005). Indeed there are numerous pros of online learning, especially in modern times, but conversely, there are some concerns that lead to the attrition of online learners and that eventually impede the progress of online courses (McIsaac \& Gunawardena, 1996). Lack of interest or motivation is one of the main things which hinders the growth of online learning, and this way it also increases the scale of dropouts from the online courses (Aragon \& Johnson, 2008). Researchers, educationists, and other professionals are very eager to know whether e-learning is able to provide better results and academic achievements when compared with traditional learning. The answer can only be found by examining student's satisfaction and their motivation. In order to prove the point, many comparative studies have been conducted to examine whether face-to-face or traditional methods of teaching are most effective, or whether online or blended learning is best (e.g., González-Gómez, Jeong, and Rodríguez (2016)). According to Bernard, Borokhovski, Schmid, Tamim, and Abrami (2014), in online learning, students do much better than at traditional learning, and this can be seen through the increasing rates of course completion, student's satisfaction, and their motivation levels in order to acquire more knowledge from online learning. Several studies have also reached the same conclusion that online learning gets a better result than traditional methods (Lockman \& Schirmer, 2020; Ryan, Kaufman, Greenhouse, She, \& Shi, 2016). No doubt, in this innovative and technological era, online learning is trending because of its increasing importance in the world of academics; meanwhile, there are some other researches that show that it has its limitations, or, in other words, which prioritize face-to-face learning. A comparative study conducted by Adams, Randall, and Traustadóttir (2015) shows that online learners were less successful when compared with face-to-face learners which was inferred through student's motivation, satisfaction, and attendance. Powers, Brooks, Galazyn, and Donnelly (2016) concluded that, in addition to the prior observation, these hybrid learners received lower grades in examinations when compared with face-to-face learners, because face-to-face learners had the immediate, physical help of the educator to clarify any tough concepts, and to direct their queries to, but this was not the case with online learners. Course design in both types of learning also plays an important role in getting good results and eventually influences student satisfaction (Lee, 2014). The pandemic of COVID19 has pushed every educational institute towards online learning, although nobody was ready for this transition. Many studies recognized the shift towards online learning as forceful, but important for continuing the learning process (Bao, 2020; Halim, Hashim, \& Yunus, 2020; Hodges, Moore, Lockee, Trust, \& Bond, 2020; Yee, 2013; Zhu, Chen, Avadhanam, Shui, \& Zhang, 2020). The suddenness of this shift initiated the debate about the quality of learning and student satisfaction. This study aims to examine a cross-country analysis of students' perceived learning and satisfaction. The mediating variable of students' perceived learning during this crisis may influence student satisfaction; however, the direct effect of variables on student satisfaction will also be examined. There have been many studies on online learning examining student satisfaction, acceptance of e-learning, success factors of distance learning, and quality of learning. The pandemic of COVID19 has forced educational institutes, including instructors and learners, to move online, with which they were not familiar (Henriksen, Creely, \& Henderson, 2020). The students were not psychologically ready for such a shift; therefore to understand how students perceived the outcome of this transition and how satisfied they are with it will be investigated in this study.

\section{Literature Review}

\subsection{Interaction}

The interaction for online courses can take place through the use of both synchronous tools (videoconferencing, audio channels, online chat rooms) and asynchronous tools (e-mail, discussion boards) (Alamri \& Tyler-Wood, 2017). Ku, Tseng, and Akarasriworn (2013) suggested in online courses specifically, interaction is an important factor for perceived student learning and motivation. Moore (2002) found instructor-learner interaction to be the most significant factor in "student satisfaction" as well as in "student learning outcomes."

Muirhead (2005) suggested that instructors need the proficiency to design course structures that encourage social interaction and uphold demanding academic principles, while nurturing self-governing learning skills. Knapp (2018) stated that online classes have been using the Learning Management System (LMS) for many years, but that the system often lacks the valuable collaborative spaces for students to do real-time, collective discussion and learning. Alqurashi (2019) found that learner-content and learner-instructor interactions are very important for student perceived learning and satisfaction, however, learner-learner interaction is not such an important predictor. H1: Interaction in online classes has a positive influence on students' perceived learning

\subsection{Student Motivation}

Motivation is an internal force that pushes a person to take an action or move toward a goal (Harmon-Jones, Harmon-Jones, \& Price, 2013). Cole, Feild, and Harris (2004) defined student motivation as the power, creativity, and readiness of students to learn and participate in classroom learning. Kanuka and Jugdev (2006) suggested that remoteness and disconnectedness in the online environment may increase the student dropout rate, as well as the feeling of remoteness that may reduce the motivation to learn (Inoue, 2007). Bolliger, Supanakorn, and Boggs (2010) stated that motivation is an important factor to keep students satisfied in an online classroom setup. Students with high motivation will be more successful in the online environment than students with low motivation (Barbour \& Reeves, 2009; Hsu, Wang, \& Levesque-Bristol, 2019; Nelson, Oden, \& Williams, 2019). 
Bulić and Blažević (2020) suggested a reverse relation of student motivation with online teaching. The modern teaching methods and online environment increase student motivation to learn in that environment. The learning environment also influences human motivation. A case study of adult students of distance education by Chyung, Winiecki, and Fenner (1998) stated that the reason for dropouts from online courses is the dissatisfaction with the learning environment. Gray and DiLoreto (2016) stated that graduate students are often more self-motivated, therefore online learning doesn't affect their learning outcome and need for interaction with peers online. Also, Chen and Jang (2010) did not find a significant association between self-determined motivation and students' learning outcomes.

H2: Motivation in an online class has a positive influence on the students' perceived learning.

\subsection{Course Structure}

Moore. (1991) defined the course structure as "expresses the rigidity or flexibility of the program's educational objectives, teaching strategies, and evaluation methods," and as "the extent to which an education program can accommodate or be responsive to each learner's individual needs." The course structure is the usefulness of the topics and organization of these topics in such a way to make it logical and understandable by a student. The course structure is the development, organization, design, curriculum, pedagogies and methodologies, timeline, and overall planning of a course before, during, and after a course is taught (Aduojo, 2018; Garrison, Anderson, \& Archer, 2000; Julia, Hakim, \& Fadlilah, 2019). This logical and understandable organization will help to increase learning outcomes and eventually help to enhance student satisfaction in the course. Instructors develop a plan about the expected learning, outcomes, assignments dates, rubrics, and guidelines for assignments to facilitate student learning and positive outcomes (Gray \& DiLoreto, 2015). Eom, Wen, and Ashill (2006) found course structure significantly influencing student satisfaction, which is similar to the findings of Gray and DiLoreto (2016). However, Eom et al. (2006) concluded that there is an insignificant relationship between in course structure and the learning outcome, which contradicts the findings of Gray and DiLoreto (2016).

H3: The course structure of an online class has a positive influence on the students' perceived learning.

\subsection{Instructor Knowledge and Facilitation}

The role of an instructor in an online environment is to encourage, guide, and invoke critical thinking in students with autonomy and accountability, rather than using traditional teaching (Huynh, 2005). In online environments, to be a good instructor and have steadfast technological equipment is crucial (Bolliger, 2004; Michael, Maithya, \& Cheloti, 2016). Jones (2006) stated that the instructor should facilitate the discussion in an online class not only between learner and instructor, but also between learners. The importance of facilitation and social presence, driven by the instructor, is an important determinant of online learning quality (Ladyshewsky, 2013). Eom et al. (2006) found instructor knowledge and facilitation significantly influenced student satisfaction, however was insignificant in determining the learning outcome.

H4: Instructor knowledge and facilitation in online classes have a positive influence on the students' perceived learning.

\subsection{Student Perceived Learning}

Students' perceived learning and student satisfaction together can represent a better understanding of online learning success Gray and DiLoreto (2016). Richardson and Swan (2003) suggested a high correlation between students' overall perceived learning with students' satisfaction in online learning. The same high correlation was substantiated by Swan (2001) and Duque (2014). Marks, Sibley, and Arbaugh (2005) stated that an immediate result of a successful learning experience is a satisfied student, and found that the perceived student learning outcome is a good predictor of student satisfaction in online learning. Ikhsan, Saraswati, Muchardie, and Susilo (2019) found that perceived learning outcomes contributed to student satisfaction and positively influence it in the online environment. Hence, hypothesis $\mathrm{H} 5$ is proposed.

H5: Students' perceived learning in online class has a positive influence on student satisfaction.

\section{Methods}

Data was collected through a research instrument administered in English. Data were collected from 100 undergraduate students from different institutions and courses in both South Korea and India. The data was collected through convenience sampling and students who were taking online courses during the pandemic COVID19 were asked to complete the survey. The items of the variables shown in Figure 1 were taken from previous studies of Eom. and Ashill (2016) and Ikhsan et al. (2019). The response of the items was taken on a 5point Likert scale. The data was analyzed using the SPSS-AMOS package 25.0 through various statistical tests.

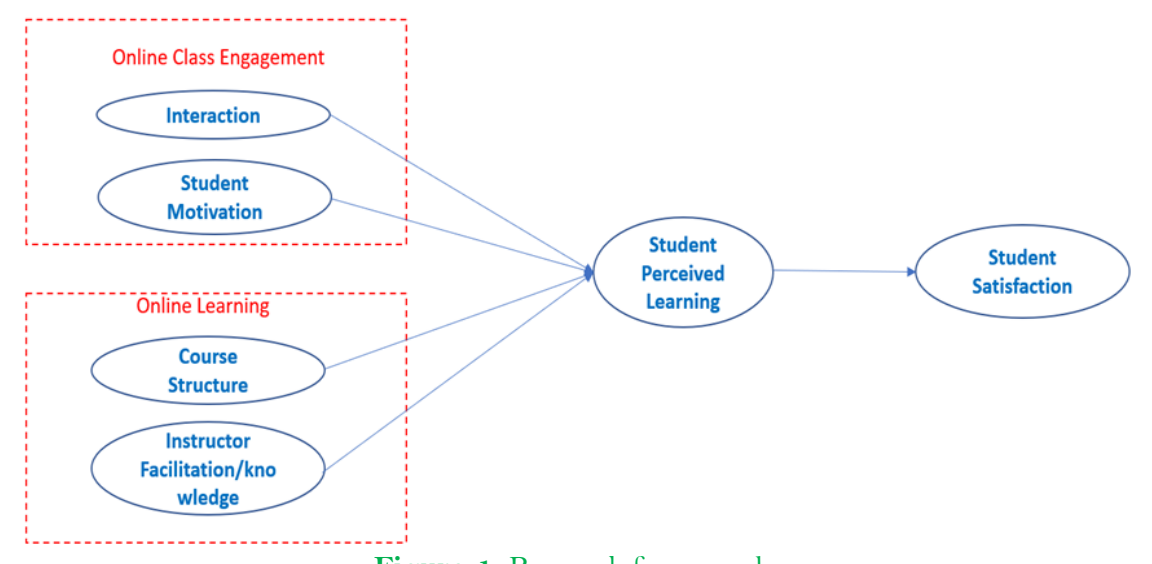

Figure-1. Research framework. 


\section{Analysis and Results}

Table-1. Demographic profile.

\begin{tabular}{c|c|c}
\hline Item & Options & Frequency \\
\hline Age & $18-22$ & 79 \\
\hline & $22-26$ & 21 \\
\hline Gender & Female & 43 \\
\hline & Male & 57 \\
\hline Nationality & South Korea & 50 \\
\hline Experience of online learning & India & 50 \\
\hline & Enough & 24 \\
\hline & None & 27 \\
\hline
\end{tabular}

Most of the respondents were in the age group $18-22$, as the sample was of undergraduates. The male population was a little higher than female respondents as shown in Table 1. Exactly 50 respondents were taken from each country. Almost 50\% of respondents had no previous experience in online education. The mean and standard deviation of each variable was estimated as presented in Table 2 . The reliability of the data was estimated and the alpha value of each construct was higher than 0.7, which is the threshold level (Baber, 2019; Devisakti \& Ramayah, 2019).

\begin{tabular}{|c|c|c|c|c|}
\hline Construct & Item & Mean & SD & Cronbach's Alpha \\
\hline \multirow[t]{3}{*}{ Interaction } & Interaction 1 & \multirow[t]{3}{*}{2.57} & \multirow[t]{3}{*}{1.04} & \multirow[t]{3}{*}{.944} \\
\hline & Interaction 2 & & & \\
\hline & Interaction3 & & & \\
\hline \multirow[t]{4}{*}{ Student Motivation } & Stu_Mot1 & \multirow[t]{4}{*}{2.88} & \multirow[t]{4}{*}{1.12} & \multirow[t]{4}{*}{.901} \\
\hline & Stu_Mot2 & & & \\
\hline & Stu_Mot3 & & & \\
\hline & Stu_Mot4 & & & \\
\hline \multirow[t]{3}{*}{ Course Structure } & Course_str 1 & \multirow[t]{3}{*}{2.97} & \multirow[t]{3}{*}{1.23} & \multirow[t]{3}{*}{.908} \\
\hline & Course_str 2 & & & \\
\hline & Course_str3 & & & \\
\hline \multirow{3}{*}{$\begin{array}{l}\text { Instructor } \\
\text { Facilitation/knowledge }\end{array}$} & Ins_Fac1 & \multirow[t]{3}{*}{3.18} & \multirow[t]{3}{*}{1.43} & \multirow[t]{3}{*}{.889} \\
\hline & Ins_Fac2 & & & \\
\hline & Ins_Fac3 & & & \\
\hline \multirow[t]{4}{*}{ Student Perceived Learning } & SPL1 & \multirow[t]{4}{*}{3.06} & \multirow[t]{4}{*}{1.31} & \multirow[t]{4}{*}{.979} \\
\hline & SPL2 & & & \\
\hline & SPL3 & & & \\
\hline & SPL4 & & & \\
\hline \multirow[t]{4}{*}{ Student Satisfaction } & Std_satisf1 & \multirow[t]{4}{*}{3.37} & \multirow[t]{4}{*}{1.07} & \multirow[t]{4}{*}{.883} \\
\hline & Std_satisf2 & & & \\
\hline & Std_satisf3 & & & \\
\hline & Std_satisf4 & & & \\
\hline
\end{tabular}

The result of regression suggests that all hypotheses are accepted as shown in Table 3. There is a strong influence of interaction in an online class together with student motivation on the student's perceived learning. While moderate influence of course structure and instructor facilitation/knowledge is on student perceived learning outcome. The student perceived learning also positively affects student satisfaction in online classes during the pandemic. The indirect effect of all four variables is significant on the dependent variable of student satisfaction as shown in Table 4. There is no significant difference between the countries students in terms of student perceived learning and student satisfaction as shown in Table 5 . The path coefficients values and $\mathrm{R}$ square values of student perceived learning outcome and student satisfaction are shown in Figure 2.

\begin{tabular}{l|l|l|l|l|l|l}
\hline Hypothesis & $\begin{array}{l}\text { Independent } \\
\text { variables }\end{array}$ & & Dependent variables & $\boldsymbol{\beta}$ & CR & Remarks \\
\hline $\mathrm{H} 1$ & Interaction & $\rightarrow$ & $\begin{array}{l}\text { Student perceived learning } \\
\text { outcome }\end{array}$ & $.669^{*}$ & 9.40 & Accepted \\
\hline $\mathrm{H} 2$ & Student motivation & $\rightarrow$ & $\begin{array}{l}\text { Student perceived learning } \\
\text { outcome }\end{array}$ & $.468^{*}$ & 6.18 & Accepted \\
\hline $\mathrm{H} 3$ & Course structure & $\longrightarrow$ & $\begin{array}{l}\text { Student perceived learning } \\
\text { outcome }\end{array}$ & $.156^{*} *$ & 2.43 & Accepted \\
\hline $\mathrm{H} 4$ & $\begin{array}{l}\text { Instructor } \\
\text { facilitation/knowledge }\end{array}$ & $\begin{array}{l}\text { Student perceived learning } \\
\text { outcome }\end{array}$ & $.114^{*} * *$ & 1.82 & Accepted \\
\hline $\mathrm{H} 5$ & $\begin{array}{l}\text { Student perceived } \\
\text { learning outcome }\end{array}$ & $\rightarrow$ & Student satisfaction & $.460^{*}$ & 3.89 & Accepted \\
\hline
\end{tabular}

Note: $* \mathrm{p}<0.01,{ }^{*} * \mathrm{P}<0.05,{ }^{*} * \mathrm{p}<0.1$ 
Table-4. Indirect effects.

\begin{tabular}{l|l}
\hline Path relationships & Estimates \\
\hline Interaction $\rightarrow$ Student perceived learning outcome $\rightarrow$ Student satisfaction & .308 \\
\hline Student Motivation $\rightarrow$ Student perceived learning outcome $\rightarrow$ Student satisfaction & .215 \\
\hline Course Structure $\rightarrow$ Student perceived learning outcome $\rightarrow$ Student satisfaction & .072 \\
\hline $\begin{array}{l}\text { Instructor facilitation/ knowledge } \rightarrow \text { Student perceived learning outcome } \rightarrow \text { Student } \\
\text { satisfaction }\end{array}$ & .052 \\
\hline
\end{tabular}

Table-5. ANNOVA estimation.

\begin{tabular}{l|l|c|c}
\hline Controlled variable & Dependent variable & F-value & P-value \\
\hline Nationality & $\begin{array}{l}\text { Student perceived learning } \\
\text { outcome }\end{array}$ & 1.577 & .212 \\
\cline { 2 - 3 } & Student satisfaction & .311 & .579 \\
\hline
\end{tabular}

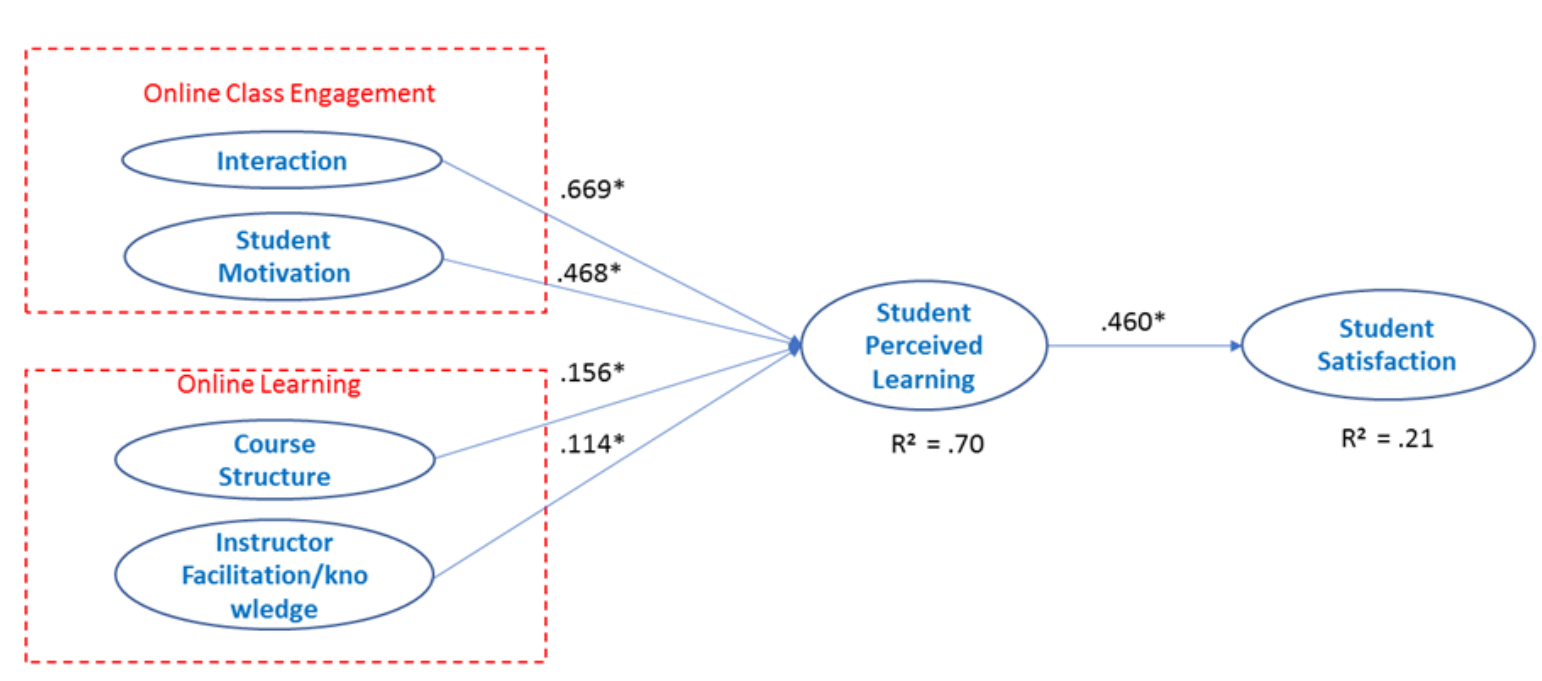

Figure-2. Model path coefficients

\section{Discussion}

The findings from literature support that online learning increases student motivation and satisfaction levels and decreases the number of online course dropouts. Additionally, literature has provided some suggestions that a balance can be created between online and offline activities. Some factors are important for the influence of the online learning experience. Much work has been undertaken to determine the importance of the factors which help in increasing the positive outcomes of online learning, but this is not concluded; more research should be done to get a clear and better understanding of the factors which influence the e-learning experience in a more productive manner, specifically during the COVID 19 pandemic. Additionally, environmental factors e.g. social distancing and perceived harm of traditional classroom teaching also influence learning outcomes and student satisfaction. While highlighting the importance of face-to-face learning for in-person interaction and physical interaction, some researches show that the absence of the face-to-face environment had condensed the interaction level among students and their instructor (Saghafi, Franz, \& Crowther, 2014). But, in the meantime, online learning, according to some researches, provides very friendly environmental factors where a professional learning environment can be changed into a more social, flexible, and personal space if needed (González-Gómez et al., 2016; Westermann, 2014). Eventually, these environmental factors add to the characteristic of the online learning experience. Saghafi et al. (2014) stated that the face-to-face learning environment has its importance which cannot be adequate with an online learning set up; according to them, both mediums have their pros and cons.

Interaction forms an important part of learning in both the offline and online setups. Interaction can take the form of instructor to learner and learner to learner. Instructor to learner interaction is vital for transferring knowledge and feedback. The importance of this interaction cannot be underestimated in both settings. The interaction in online classes is a topic of debate as electronic communication may not be as effective as traditional communication. The absence of emotions, body language, and facial expressions are significant in online classes. The results of this study are in line with the findings of Moore (2014); Sebastianelli, Swift, and Tamimi (2015); Alqurashi (2019) and $\mathrm{Ku}$ et al. (2013) which concluded that interaction between instructor and learner is an important determinant of student perceived learning and satisfaction.

Student motivation is an important element of a successful learning outcome in both offline and more online education. The online environment keeps people away from the campus and peer learners, which makes motivation a more important determinant of students' learning outcome and satisfaction. The pandemic COVID19 pushed students' online learning and becomes more important to study their motivation in this setup. The students were not ready or prepared for this learning, and their motivation to start and continue learning is essential for a positive learning outcome. The results signify that the motivation of students to study in an online environment during the COVID19 pandemic is an important determinant of the learning outcome success and satisfaction. The past studies of Bolliger et al. (2010) and Hsu et al. (2019) support the findings of this study.

The course structure had a mixed influence on student satisfaction and students' learning outcomes according to the previous studies. The results show that the course structure indirectly influences the student perceived learning outcome and student satisfaction. The results favor the findings of Gray and DiLoreto (2016) while contradicting Eom et al. (2006). The course structure of online courses during the pandemic COVID19 was not designed for online learning. The course structure was design for normal, offline learning. The course structure had to be modified to fit the needs of online learning, which may have enhanced the student learning outcome. An instructor in an online environment plays two major roles: a designer, and a facilitator (Martin, Wang, \& Sadaf, 
2018). During course instruction, the instructor has to act like a 'facilitator' for facilitating learning, and also actively engage in discussions with learners (Riva, Davide, \& IJsselsteijn, 2003). The facilitating role of the instructor and the knowledge he/she possesses influences the student learning outcome and satisfaction. There was an additional responsibility for the instructors who were teaching online classes during the pandemic. They had to adjust themselves to a changing environment, getting their technical skills polished during the process, and providing facilitation of technical expertise to the students who are new to this environment. The results show that instructor facilitation and knowledge is an important determinant for students' learning outcome and student satisfaction during online learning amid the pandemic.

Students' perceived learning outcomes and student satisfaction have been studied in the past (Gray \& DiLoreto, 2016; Ikhsan et al., 2019; Richardson \& Swan, 2003). Various factors are responsible for positive perceived learning outcome in the different contexts and courses. This study was different to the previous studies as it is important to examine the students' perception of learning during the pandemic. The students perceive interaction, motivation, course content, and the role of instructor to be key determinants of the positive learning outcome. The positive learning outcome also has an impact on student satisfaction. The higher the perceived learning outcome in online learning, the higher satisfaction of students amid the pandemic. Instructors and educational institutions should focus on bringing out positive learning outcomes through online settings during this crisis period. The satisfaction of students is a crucial part of education and is a matter of concern during the transition of learning from offline to online. The students from both countries recognize these factors are essential for a positive learning outcome and their satisfaction. Although the infrastructure of technology and education is different in both countries, there is no significant difference in the two dependent variables which were examined. The learners also understand the grave situation under which this transition has occurred and they are happy with the efforts of their institutes and instructors.

\section{Conclusion}

Online learning has arisen as an alternative to traditional learning during the pandemic. Most students have experienced online classes for the first time. Variables such as interact in the online class, student motivation to participate in the online class, course structure, and instructor facilitation and knowledge are important determinants of perceived student learning and student satisfaction. Online student engagement is a stronger determinant of the perceived student learning outcome as online classes lack physical socialization. There is no significant difference in the learning outcome and satisfaction levels of students from either country. Future studies should be done to understand the role of technology acceptance in perceived learning and student satisfaction. Future studies should also focus on the factors which are critical from the point of view of students to accept this online learning during the pandemic COVID 19.

\section{Limitations}

Due to the time constraints, only a few samples were taken from each country. The sample size will be a limitation to generalize the results. It is also important to examine the influence of perceived harm of going to offline classrooms or the apparent norm of maintaining social distancing on the student learning outcome and satisfaction.

\section{References}

Adams, A., Randall, S., \& Traustadóttir, T. (2015). A tale of two sections: An experiment to compare the effectiveness of a hybrid versus a traditional lecture format in introductory microbiology. CBE Life Sciences Education, 14(1), ar6-ar6. Available at: https://doi.org/10.1187/cbe.14-08-0118.

Aduojo, T. (2018). Effects of teaching methods on basic science achievement and spatial ability of basic Nine Boys and Girls in Kogi State, Nigeria. Humanities and Social Sciences Letters, 6(4), 149-155. Available at: https://doi.org/10.18488/journal.73.2018.64.149.155.

Alamri, A., \& Tyler-Wood, T. (2017). Factors affecting learners with disabilities-instructor interaction in online learning. Journal of Special Education Technology, 32(2), 59-69. Available at: https://doi.org/10.1177/0162643416681497.

Alqurashi, E. (2019). Predicting student satisfaction and perceived learning within online learning environments. Distance Education, 4O(1), 133-148. Available at: https://doi.org/10.1080/01587919.2018.1553562.

Aragon, S., \& Johnson, E. (2008). Factors influencing completion and noncompletion of community college online courses. American Journal of Distance Education, 22(3), 146-158.

Baber, H. (2019). E-SERVQUAL and its impact on the performance of Islamic Banks in Malaysia from the customer's perspective. The Journal of Asian Finance, Economics and Business (JAFEB), 6(1), 169-175. Available at: https://doi.org/10.13106/jafeb.2019.vol6.no1.169.

Bao, W. (2020). COVID-19 and online teaching in higher education: A case study of Peking University. Human Behavior and Emerging Technologies, 2(2), 113-115. Available at: https://doi.org/10.1002/hbe2.191.

Barbour, M. K., \& Reeves, T. C. (2009). The reality of virtual schools: A review of the literature. Computers $\&$ Education, 52(2), 402-416. Available at: https://doi.org/10.1016/j.compedu.2008.09.009.

Bates, A. W. (2005). Technology, e-learning and distance education (2nd ed.). New York: RoutledgeFalmer.

Bernard, R. M., Borokhovski, E., Schmid, R. F., Tamim, R. M., \& Abrami, P. C. (2014). A meta-analysis of blended learning and technology use in higher education: From the general to the applied. Journal of Computing in Higher Education, 26(1), 87-122. Available at: https://doi.org/10.1007/s12528-013-9077-3.

Bolliger, D. U. (2004). Key factors for determining student satisfaction in online courses. International Journal on E-learning, 3(1), 61-67.

Bolliger, D. U., Supanakorn, S., \& Boggs, C. (2010). Impact of podcasting on student motivation in the online learning environment. Computers $\mathcal{E}^{2}$ Education, 55(2), 714-722. Available at: https://doi.org/10.1016/j.compedu.2010.03.004.

Bulić, M., \& Blažević, I. (2020). The impact of online learning on student motivation in science and biology classes. Journal of Elementary Education, 13(1), 73-87.

Chen, K.-C., \& Jang, S.-J. (2010). Motivation in online learning: Testing a model of self-determination theory. Computers in Human Behavior, 26(4), 741-752. Available at: https://doi.org/10.1016/j.chb.2010.01.011.

Chyung, Y., Winiecki, D. J., \& Fenner, J. A. (1998). A case study: Increase enrollment by reducing dropout rates in adult distance education. Paper presented at the Distance Learning '98. Proceedings of the Annual Conference on Distance Teaching and Learning, Madison, WI, 97-101. (ERIC Document Reproduction Service No. ED 422848).

Cole, M. S., Feild, H. S., \& Harris, S. G. (2004). Student learning motivation and psychological hardiness: Interactive effects on students' reactions to a management class. Academy of Management Learning E Education, 3(1), 64-85. Available at: https://doi.org/10.5465/amle.2004.12436819. 
Devisakti, A., \& Ramayah, T. (2019). E-Learning usage outcomes among university learners: A pilot study. Journal of Education and eLearning Research, 6(3), 149-155. Available at: https://doi.org/10.20448/journal.509.2019.63.149.155.

Duque, L. C. (2014). A framework for analysing higher education performance: Students' satisfaction, perceived learning outcomes, and dropout intentions. Total Quality Management \& Business Excellence, 25(1-2), 1-21. Available at: https://doi.org/10.1080/14783363.2013.807677.

Eom, S. B., Wen, H. J., \& Ashill, N. (2006). The determinants of students' perceived learning outcomes and satisfaction in university online education: An empirical investigation. Decision Sciences Journal of Innovative Education, 4(2), 215-235.

Eom, S. B., \& Ashill, N. (2016). The determinants of students' perceived learning outcomes and satisfaction in university online education: An update. Decision Sciences Journal of Innovative Education, 14(2), 185-2 15.

Garrison, A., Anderson, R. T., \& Archer, W. (2000). Critical inquiry in a text-based environment: Computer conferencing in higher education. The Internet and Higher Education, 2(2-3), 87-105.

González-Gómez, D., Jeong, J. S., \& Rodríguez, D. A. (2016). Performance and perception in the flipped learning model: An initial approach to evaluate the effectiveness of a new teaching methodology in a general science classroom. Journal of Science Education and Technology, 25(3), 450-459. Available at: https://doi.org/10.1007/s 10956-016-9605-9.

Gray, J. A., \& DiLoreto, M. (2016). The effects of student engagement, student satisfaction, and perceived learning in online learning environments. International Journal of Educational Leadership Preparation, 11(1), n1.

Gray, J., \& DiLoreto, M. (2015). Student satisfaction and perceived learning in online learning environments: The mediating effect of student engagement. Paper presented at the Annual Meeting of the National Council of Professors of Educational Leadership, Washington, DC.

Halim, M. S. A. A., Hashim, H., \& Yunus, M. M. (2020). Pupils' motivation and perceptions on ESL lessons through online quiz-games Journal of Education and E-Learning Research, 7(3), 229-234. Available at: https://doi.org/10.20448/journal.509.2020.73.229.234.

Harmon-Jones, E., Harmon-Jones, C., \& Price, T. F. (2013). What is approach motivation? Emotion Revierw, 5(3), 291-295. Available at: https://doi.org/10.1177/1754073913477509.

Henriksen, D., Creely, E., \& Henderson, M. (2020). Folk pedagogies for teacher transitions: Approaches to synchronous online learning in the wake of COVID-19. Journal of Technology and Teacher Education, 28(2), 201-209.

Hodges, C., Moore, S., Lockee, B., Trust, T., \& Bond, A. (2020). The difference between emergency remote teaching and online learning. Educause Review, 27

Hsu, H.-C. K., Wang, C. V., \& Levesque-Bristol, C. (2019). Reexamining the impact of self-determination theory on learning outcomes in the online learning environment. Education and Information Technologies, 24(3), 2159-2174. Available at: https://doi.org/10.1007/s 10639-019-09863-w.

Huynh, M. Q. (2005). Viewing e-learning productivity from the perspective of Habermas' cognitive interests theory. Journal of Electronic Commerce in Organizations, 3(2), 33-45. Available at: https://doi.org/10.4018/jeco.2005040103.

Ikhsan, R. B., Saraswati, L. A., Muchardie, B. G., \& Susilo, A. (2019). The determinants of students' perceived learning outcomes and satisfaction in BINUS online learning. Paper presented at the 20195 th International Conference on New Media Studies (CONMEDIA). IEEE.

Inoue, Y. (2007). Online education for lifelong learning: A silent revolution. In Online education for lifelong learning (pp. 1-27): IGI Global.

Jones, S. (2006). Evaluation of instructor knowledge on structuring and facilitating effective online discourse. The Journal of Educators Online, 3(2), 1-14. Available at: https://doi.org/10.9743/jeo.2006.2.1.

Julia, J., Hakim, A., \& Fadlilah, A. (2019). Shifting primary school teachers' understanding of songs teaching methods: An action research study in Indonesia. International Journal of Education and Practice, $7(3), \quad 158-167$. Available at: https://doi.org/10.18488/journal.61.2019.73.158.167.

Kanuka, H., \& Jugdev, K. (2006). Distance education MBA students: An investigation into the use of an orientation course to address academic and social integration issues. Open Learning: The Journal of Open, Distance and e-Learning, 21(2), 153-166. Available at: https://doi.org/10.1080/02680510600715578.

Knapp, N. F. (2018). Increasing interaction in a flipped online classroom through video conferencing. TechTrends, 62(6), 618-624. Available at: https://doi.org/10.1007/s11528-018-0336-z.

Ku, H.-Y., Tseng, H. W., \& Akarasriworn, C. (2013). Collaboration factors, teamwork satisfaction, and student attitudes toward online collaborative learning. Computers in Human Behavior, 29(3), 922-929. Available at: https://doi.org/10.1016/j.chb.2012.12.019.

Ladyshewsky, R. (2013). Instructor presence in online courses and student satisfaction. The International Journal for the Scholarship of Teaching and Learning, 7(1), 1-23. Available at: https://doi.org/10.20429/ijsotl.2013.070113.

Lee, J. (2014). An exploratory study of effective online learning: Assessing satisfaction levels of graduate students of mathematics education associated with human and design factors of an online course. International Review of Research in Open and Distributed Learning, 15(1), 111-132. Available at: https://doi.org/10.19173/irrodl.v15i1.1638.

Lockman, A. S., \& Schirmer, B. R. (2020). Online instruction in higher education: Promising, research-based, and evidence-based practices. Journal of Education and e-Learning Research, 7(2), 130-152.

Marks, R. B., Sibley, S. D., \& Arbaugh, J. B. (2005). A structural equation model of predictors for effective online learning. Journal of Management Education, 29(4), 531-563. Available at: https://doi.org/10.1177/1052562904271199.

Martin, F., Wang, C., \& Sadaf, A. (2018). Student perception of helpfulness of facilitation strategies that enhance instructor presence, connectedness, engagement and learning in online courses. The Internet and Higher Education, 37, 52-65. Available at: https://doi.org/10.1016/j.iheduc.2018.01.003.

McIsaac, M. S., \& Gunawardena, C. N. (1996). Distance education. In D. H. Jonassen (Ed.), Handbook of research for educational communications and technology (pp. 403-437). New York: Macmillan.

Michael, F. M., Maithya, R., \& Cheloti, S. K. (2016). Influence of teacher competency on integration of ICT in teaching and learning in public secondary schools in Machakos. Journal of Education and e-Learning Research, 3(4), 143-149. Available at: https://doi.org/10.20448/journal.509/2016.3.4/509.4.143.149.

Moore, M. G. (2002). Editorial, what does research say about the learners using computer-mediated communication in distance learning? The American Journal of Distance Education, 16(2), 61-64. Available at: https://doi.org/10.1207/s15389286ajde1602_1.

Moore, M. G. (1991). Editorial: Distance education theory. American Journal of Distance Education, 5(3), 1-6.

Moore, J. (2014). Effects of online interaction and instructor presence on students' satisfaction and success with online undergraduate public relations courses. Journalism \& Mass Communication Educator, 69(3), 271-288. Available at: https://doi.org/10.1177/1077695814536398.

Muirhead, B. (2005). A Canadian perspective on the uncertain future of distance education. Distance Education, 26(2), 239-254. Available at: https://doi.org/10.1080/01587910500168884.

Nelson, M. L., Oden, K. L., \& Williams, L. L. (2019). Student motivation to participate in asynchronous on-line discussions.

Powers, K. L., Brooks, P. J., Galazyn, M., \& Donnelly, S. (2016). Testing the efficacy of MyPsychLab to replace traditional instruction in a hybrid course. Psychology Learning \& Teaching, 15(1), 6-30. Available at: https://doi.org/10.1177/1475725716636514.

Richardson, J., \& Swan, K. (2003). Examing social presence in online courses in relation to students' perceived learning and satisfaction. JALN, 7(1), 68-88.

Riva, G., Davide, F., \& IJsselsteijn, W. A. (2003). Being there: Concepts, effects and measurements of user presence in synthetic environments: Ios Press.

Ryan, S., Kaufman, J., Greenhouse, J., She, R., \& Shi, J. (2016). The effectiveness of blended online learning courses at the community college level. Community College Journal of Research and Practice, 40(4), 285-298. Available at: https://doi.org/10.1080/10668926.2015.1044584.

Saghafi, M. R., Franz, J., \& Crowther, P. (2014). An integrated blended model for the contemporary learning environments. Journal of Interactive Learning Research, 25(4), 531-549.

Sebastianelli, R., Swift, C., \& Tamimi, N. (2015). Factors affecting perceived learning, satisfaction, and quality in the online MBA: A structural equation modeling approach. Journal of Education for Business, 90(6), 296-305. Available at: https://doi.org/10.1080/08832323.2015.1038979. 
Swan, K. (2001). Virtual interaction: Design factors affecting student satisfaction and perceived learning in asynchronous online courses. Distance Education, 22(2), 306-331. Available at: https://doi.org/10.1080/0158791010220208.

Westermann, E. B. (2014). A half-flipped classroom or an alternative approach?: Primary sources and blended learning. Educational Research Quarterly, 38(2), 43-57.

Yee, R. C. S. (2013). Perceptions of online learning in an Australian University: Malaysian students' perspectives usability of the online learning tools. International Journal of Asian Social Science, 3(9), 1973-1981. Available at: https://doi.org/10.7763/ijiet.2015.v5.573.

Zhu, X., Chen, B., Avadhanam, R. M., Shui, H., \& Zhang, R. Z. (2020). Reading and connecting: Using social annotation in online classes. Information and Learning Sciences, 121(5/6), 261-271. 